\title{
Content and use of colonial archives: an under- researched issue
}

\author{
Ellen Ndeshi Namhila
}

Published online: 11 September 2014

(C) The Author(s) 2014. This article is published with open access at Springerlink.com

\begin{abstract}
Namibians often find themselves in situations of litigation where they need person-related records to defend their rights and privileges. Such personrelated records include birth, adoption, marriage, or divorce or deceased estates. It has been observed that the institution where such records should be expected, the National Archives of Namibia often cannot retrieve person-related records of persons previously classified as non-whites under colonial and apartheid laws. Many native Namibians end up losing property or have problems claiming their constitutional rights due to lack of evidence. The purpose of this paper was to explore whether the existing archival literature can guide National Archives of new and emerging African nations on how to handle challenges brought about by gaps in inherited colonial archives. Using a literature survey to explore the state of what is written on the content and usage of colonial archives in post-colonial era, this article argues that the content and use of colonial archives in Africa do not feature prominently in the literature of archival science. Although there has been a rising interest on the subject during the last decade, none of this emerging literature has systematically studied archives in depth with a view on what these archives contain for the non-academic user, what they neglect and what they lack altogether in serving the needs of all citizens in post-colonial states. It recommends that archival scholars as well as archival institutions increase research into this neglected area. Raising awareness may produce academic discourse to help archivists in newly decolonised countries to competently support users whose inquiries currently cannot be answered by the inherited colonial archives collections.
\end{abstract}

E. N. Namhila $(\bowtie)$

University of Namibia, 340 Mandume Ndemufayo Avenue,

Private Bag 13301, Pionierspark, Windhoek, Namibia

e-mail: enamhila@unam.na; enamhila@gmail.com

URL: http://www.unam.na 
Keywords Colonial archives - Recordkeeping practices - Post-colonial studies · Vital records · National Archives · Africa · Namibia

\section{Introduction}

In this article, I share the experiences of an archival institution transitioning from an archives depot of a colonised territory to the National Archives of Namibia (NAN), an independent nation state. Whilst there is evidence that recordkeeping practices developed amongst the indigenous people of Namibia before colonisation, and surviving paper records from this period are accessible at the NAN (NAN A.0002; A.0003; A.0650), this record-producing culture amongst the indigenous people of Namibia seems to have ceased, or rather, to have been nipped in the bud by the abolition of indigenous governance structures during the colonial period. The German empire, which colonised Namibia between 1884 and 1915, introduced a fairly sophisticated recordkeeping system at all levels, but refrained from civil registration of "natives". It did not establish an archival institution in the colony.

Whilst the records of the central civil German administration, including the judiciary, have largely been preserved intact (with a few exceptions), the vast majority of German military records must be considered destroyed and the German civil district administration records suffered serious losses through unauthorised destruction by South African officials before the establishment of the Archives Depot of the Territory (later National Archives) (Hillebrecht 2013). The NAN was established as "Archives Depot of the Territory of South West Africa" in $1939 .{ }^{1}$ It initially secured the surviving German records and later continued to archive civil administration as well as judicial records from the period under South African rule (1915-1990). The National Archives emerged following the country's transition from being a South African colony to an independent nation on 21 March 1990.

About $95 \%$ of the total collections at the NAN are archives of German and South African colonial administrations. Records from the final years of South African rule (c.1965-1990) including records from the "Bantustans" established during this period remain, to a substantial part, poorly organised and difficult to access. Apart from these records and (still comparatively few) government records from independent Namibia (1990-), the NAN houses rich private accessions of personal papers including a few collections of pre-colonial authorities.

My motivation in writing this article is my observation that many requests by Black Namibians for person-related records, such as adoption and divorce records as well as those of deceased estates, can rarely be served by the NAN despite intensive and time-consuming searches. An entire archival fonds of "native estates" comprising ca.7000 files remain unlisted and not indexed (NAN: NES). The same

\footnotetext{
1 The "Mandated Territory of South West Africa" was, in South African parlance, often just referred to as "The Territory". In 1966, the United Nations General Assembly revoked the Mandate (see: United Nations 1966), but South Africa disputed the responsibility of the UN and continued to occupy Namibia illegally until the country attained independence on 21 March 1990.
} 
types of requests by White Namibians are fulfilled without problems within minutes (e.g. from the fully computer-indexed fonds of "white estates", NAN: EST). There are similar problems with birth, death, and marriage records, although the administration of those records does not lie within the authority of the National Archives, as they are kept by the Ministry of Home Affairs. ${ }^{2}$ The availability of employment records, required for the settlement of pension claims, is another problem area.

I have chosen to use the term person-related records in the context of this paper. I define this as records that supply official and legally valid information about life events, marital status, ancestry, offspring, residency, religious affiliation, employment, property, as well as other vital details. Given the German influence on the colonial records, this definition is modelled on the German term "personenbezogene Unterlagen". The English term vital records, commonly used for governmental birth, death, marriage, and divorce records, is ambiguous in archival use as it is also widely used in records management for "records, regardless of medium, which are essential to the organisation in order to continue with its business-crucial functions both during and after a disaster" (Wikipedia: Vital record).

The significance of person-related records lies in several domains. They confirm rights and privileges of individual citizens; they confirm identities, both official (for example, as proof for citizenship rights) and private (as belonging to a family, to a community or to a cultural heritage), and carry proof of economical transactions (such as inheritance in estate records). Person-related archives in the form of paper records became increasingly important from 1990 when Namibia gained its independence from neighbouring South Africa and its apartheid policies in a combined military and diplomatic liberation struggle. Persons previously accorded "Native" status became full citizens in a non-segregated society. The onset of independence made these records more important to people in their pursuit of personal development, and in the processes of urbanisation, rural-to-town migration, and the re-integration of the substantial exiled population. The NAN could often not find their records despite the willingness of the staff to search long and hard.

As the Director: Namibia Library and Archives Services under the Ministry of Education (1999-2007), I observed challenges emanating from frequent gaps in the archival collections. Although I was not involved in the day-to-day administration of the archives, various issues concerning the use of archival records came to my knowledge.

A typical example features a young Black Namibian man in search of his father's divorce papers, which he urgently needed to resolve a case of inheritance following the father's sudden death. It was alleged that the father never officially divorced the first wife before he married the young man's mother and if proven, the law would only recognise the first wife, treating the second wife and her children as illegitimate. The family held that he divorced in Walvis Bay in 1979; the Magistrate

\footnotetext{
2 The problem with birth, marriage and death records has been complicated by the fact that these records had been removed during colonial times to the South African Department of Home Affairs, which is in the process of returning them to Namibia. The Namibian Ministry of Home Affairs has embarked upon digitising these records, and a meaningful enquiry about their coverage will only be possible after this process has been finalised.
} 
Court in Walvis Bay claimed that they had no records from that period because they were transferred to the Archives depot in Windhoek. However, no divorce records for "Natives" from Walvis Bay could be found in the NAN.

In another case, the family of a recently deceased prominent businessman needed to find the estate of his predeceased wife to finalise the distribution of his own estate. Again, no estate records could be found.

In a final example, an adopted "mixed-race" child needed legal proof of his adoption in an inheritance case. The case number in the register of adoptions was located, but the relevant case file was missing. Such glaring gaps in the records have been observed for adoptions, divorces, and deceased estates of "Natives".

These types of questions by citizens looking for their past or looking for evidence to protect their rights and privileges inspired me to investigate the literature to determine how National Archives of other decolonised nations dealt with corresponding issues. I found that the structural divisions of apartheid policies and practices during colonial Namibia have been reproduced in the other nation's archival records and that these archives are "national" in name only; the records perpetuate apartheid. When person-related inquiries for a majority of citizens cannot be answered, this violates their constitutional rights. Other legacies of the colonial past such as educational, economic, and land ownership disparities are all being addressed by dedicated policies of the post-colonial state. The archival legacy of discriminatory treatment remains unchallenged. As a result, it causes reputational damage to the image, character, and integrity of archives as an institution of public faith.

I had hoped that archival literature especially from decolonised African countries would provide the much needed learning experiences for archivists in Namibia in their effort to assist users whose questions could not be answered by the contents of the archives; or, alternatively, to establish whether the alleged absence of personrelated archives of the Natives was an isolated Namibian case without global significance.

In the context of this paper, I define colonial archives as both archival records and archival institutions that were created and maintained under colonial rule, that is, in the political context of a territory that is not sovereign but ruled by another country in a colonial situation. This assumes a social context where people are treated in a discriminatory manner according to their ethnicity, race, or origin (UNESCO 1990, p. $143 \mathrm{ff}$ ). The timeframe of this definition extends beyond the formal independence of a country, because the colonial archival heritage remains as such, and its character is not automatically changed by a country's new legal status given that the legacy of previous recordkeeping practices persists in the content of colonial archives, if not in the new country's governmental offices.

Namibia, which before its independence had sometimes been labelled "the last colony" (Green et al. 1981; Wallace 2011), was one of only two countries, the other being South Africa, that suffered institutionalised racism in the specific form of "apartheid" (United Nations 1982), and it was colonised for 106 years. It might therefore have been particularly affected by the phenomenon of discriminatory treatment of person-related records, and as a settler colony with a sizeable White population, thus, any differential treatment would appear more obvious and 
detectable. It is therefore an appropriate case study subject. However, it is well known that many (if not all) countries under colonial rule were subject to discriminatory treatment of the colonized people, even if this might take a more "benevolent" form of paternalism and indirect rule (UNESCO 1990, p. 143 ff.). Therefore, a closer investigation of the literature focusing on the content of colonial archives and its impact on use by citizens of emerging nations would be a significant contribution to archival science that is not limited to the specific case of Namibia.

\section{Previous studies on content and use of colonial archives}

I conducted a search for literature on the content and use of colonial archives through a Boolean Internet search with various relevant keyword combinations (colonies, archives, records, content, person-related, natives, etc.) in relevant databases, such as JSTOR, EBSCO HOST, DOAJ, Emerald, Springer Link, and by evaluation of an African archival journal. The review revealed that the coverage of person-related records relating to colonial recordkeeping practices does not feature prominently in the archival science literature, although there has been a rising interest in colonial archives during the last decade. The following review is not a comprehensive review of the entire and growing literature about colonial archives, but tries to identify and exemplify trends.

I found it striking that none of this emerging literature has actually studied an archives in depth with a view to what these archives contain, what they neglect, what they lack altogether. Studies about the problems of archives in decolonised countries, and in particular African countries, tend to focus on problems of current and semi-current records management (e.g. Tough 2009), maintenance, and preservation (e.g. Ngulube 2005), training (e.g. Kigongo-Bukenya 1993), and occasionally on displaced archives (e.g. Banton 2012). This pattern is repeated in general overview articles (e.g. Mnjama 2005). When questions about content are asked, they focus on academic issues of historiography: whether or how the records reflect realities or actual processes (if one approaches from the side of traditional history writing, e.g. Arondekar 2005); or how the colonial process of archiving shapes historical perception (if one follows a postmodernist approach, e.g. Stoler 2002). The issue that (apart from their academic research value) archives have a highly practical value for ordinary citizens, and how these citizens' expectation can be fulfilled, is rarely addressed-if at all.

Even the highly innovative volume "Refiguring the archive" (Hamilton et al. 2002) is silent about the issue of use, although it originated from a 1998 seminar series at the University of the Witwatersrand to explore the argument "that the country's [South Africa's] archives require transformation, or refiguring" (p. 7). The book's introduction acknowledges Foucault's influence "in the proposition [...] that archives are often both documents of exclusion and monuments to particular configurations of power" (Hamilton et al., p. 9). The mundane issue of how these exclusions and configurations of power have shaped simple but vitally important issues, such as the availability of vital documents to ordinary citizens, is not 
explored. In his article "The archival sliver", Harris (2002) provides a sweeping overview of the Apartheid State's destruction and exclusion of documents. Researching the many leads Harris provides about this history would warrant a volume on its own, but the issue of simple "unpolitical" person-related records is not mentioned. Interestingly, in the same article, Harris remarks in a footnote that "From the 1980s the State Archive Service [of apartheid South Africa] began shaping its user services around the needs of its largest clientele groupinggenealogical (almost exclusively white) researchers", without further reflecting about the implications of this subject for black archives users, then and 20 years later" (Harris 2002, p. 139 ff 16). The issues of person-related records, their availability and use are simply not covered in this literature.

Even the brilliant exposé by Mwiyeriwa (1985), which (despite being obsolete in technical detail) to this day remains an excellent and almost comprehensive introduction to the subject of African archival problems, is silent about the gaps in colonial archival collections and the implications of those gaps. Likewise, the very perceptive up-to-date overview by Mazikana (1997), who picks up looming problems that many African archivists have yet to realise, such as the records of privatised state functions slipping through their fingers, does not touch the issue of inherited content, except for the need to complement it with oral history and repatriated records that were migrated and displaced by former colonial powers. The latter remains a contentious issue and may be larger than previously acknowledged, as the recent (2012/2013) opening, but not repatriation, of displaced colonial records at the National Archives of the United Kingdom indicates (The National Archives [UK] 2013; Banton 2012). The lack of recognition in the literature of the subject coverage of archival collections as a problem leaves that issue to the historians, sociologists, and anthropologists.

Lihoma (2012) presents one of the few recent detailed historical country studies of African archives and records management. Whilst he compares the records management and archives service in colonial Nyasaland favourably with the postcolonial situation in Malawi under the dictatorship of Dr. Hastings Banda, he does not touch on the issue of person-related records. Lihoma, however, prominently mentions the extensive destruction and displacement of records at the end of British rule in Malawi. This issue, affecting many former colonies, has only quite recently come to wider public attention (Banton 2012). Given the current situation of public access to the National Archives of Malawi, which still operates under the restrictive legal provisions of the Banda regime (requiring research permission by the Minister), it is not surprising that possible gaps in person-related records have not been brought to attention through enquiries from the public. It is the wider opening of the Namibian archives to citizens' use, initiated immediately after independence by the then Director Brigitte Lau (Lau 1993), that alerted the Namibian archives to the problem of gaps.

One particular trend in the literature on colonial archives is rather obviousalthough it appears strange when treating an institution that is considered the primary source par excellence: Many authors rely solely on secondary sources and reiterate what others have already observed (or copied) elsewhere. A few examples of such works shall be mentioned in the following. Bastian (2006) provides a 
comprehensive overview of attitudes and use of archives by post-colonial scholars who find that colonial records offer the voices of the master narrative but do not reflect the voices of the oppressed and voiceless. She refers to the adage that "history is written by the winners" which is befitting to the understanding of colonial archives because the archival records were also created by the winners (Bastian 2006, p. 268). In post-colonial societies, the colonial archives have been subject of scholarly research to read them "against the grain" in an effort to extract information and voices that had been silenced. These are common themes through much of the literature on colonial archives. What is, however, not mentioned is that not only voices had been silenced but even the mere evidence of the existence of individuals amongst the oppressed appears to have been erased or ignored to a large extent. Furthermore, that erasure continues as current citizens are still affected by these silences in their daily lives.

McEwan (2003) examines the "collective memory of black women, who have often been most marginalized by colonialism and apartheid and excluded from the dominant accounts of history" (McEwan 2003, p. 739). McEwan cites Bellamy and Shetty (2000, p. 27) with the perceptive formulation "palimpsestic narrative of imperialism". The palimpsest, the ancient writing that was erased to make space for a different narrative, is a powerful symbol for the history and culture of the colonised being erased by colonialism and Christianity.

Josias (2011) refers to a number of emerging projects in South Africa to recover and record memory. She cites Lalu concerning the District Six Museum in Cape Town: "Unlike the archives of the state, which produces pre-packaged communities with labels and postal addresses, the Museum inaugurates the concept of the archive that envisages the meaning of a post-apartheid community through the remnants of one that apartheid destroyed" (Josias 2011, p. 98). Lalu might have drawn a false dichotomy: the archive of the state, in all its "prepackaged" apartheid conception, is not the monolithic unchangeable block that its apartheid creators may have wished to shape. It is up to the receivers of that legacy to look through the cracks and earn the legacy by discovering and using the hidden information to reconstruct what has been destroyed. Even the efforts to destroy a community will leave evidence of its existence.

A Namibian example, in a context similar to the District Six Museum, is the extraction of house ownership information in Windhoek's destroyed "Old Location" from the records of the City of Windhoek. To remove the "black spot" Old Location which accommodated black residents close to the centre of Windhoek and resettle its inhabitants to the distant Katutura, the apartheid municipality recorded and assessed houses for the purpose of monetary compensation for the structures that were destroyed in the process. This tool of destruction, duly preserved, has recently been turned into a database assisting the memory of former inhabitants to reconstruct and to record oral information about the face and social life of the Old Location. Like the South African examples mentioned above, this database was a civil society initiative (NAN AACRLS.292).

This, however, is a work that well-established archives of the state rarely undertake. Efforts to unearth the history of colonial and repressive regimes "from below" are often coming from institutions that were newly established by civil 
society, and characteristically also from institutions blurring the distinctions between archives, museums, and libraries. The South African District Six Museum, the Mayibuye Centre, the South African History Archive (SAHA), and the Nelson Mandela Foundation are cases in point. ${ }^{3}$ But whilst they are focusing on personal memory, non-governmental records of the liberation struggle, and state records of political oppression, none of them seems to touch upon the issue of routine personrelated records. Which is, of course, also not their task: the recording and archiving of civic person-related records are a basic state function.

None of these studies on colonial and post-colonial archives attempt to qualify and quantify the extent of colonial recordkeeping gaps in the archives of postcolonial nation-states. One can confidently state that, whilst the problematic nature of the use of colonial archives as a source of information has been widely discussed, an empirical study on the absence or inaccessibility of certain information in colonial archives is sorely missing. In addition, none of the literature on postcolonial archives (with the possible exception of Josias (2011)) takes the needs of the non-academic user into consideration: all studies lamenting the one-sidedness of colonial archives are written from the standpoint of the academic researcher.

One can also state that the awareness of this problem amongst African archivists is acutely lacking and that whilst lamenting the lack of a recordkeeping culture amongst post-colonial government bureaucracies, they fail to realise, and might possibly perpetuate, the shortcomings of colonial recordkeeping and archiving practices. This can be exemplified with an analysis of the subjects of articles in the 2001-2013 issues of Eastern and Southern African Regional Branch of the International Council on Archives (ESARBICA) journal, a leading archives journal in Eastern and Southern Africa. A classification of articles by subject coverage revealed the following trend: out of a total of 152 articles, 44 articles dealt with records management (including electronic records management); 25 articles with preservation and maintenance; 18 with access including "Freedom of Information"; 17 with use of information technology (i.e. digitisation, excluding electronic records management); 14 with oral history and indigenous knowledge; 12 with general questions of archival management, such as appraisal and description; 8 with archival training; and 6 articles dealt with various other subjects. The general trend is corroborated by Mnjama's examination of resolutions at ESARBICA conferences (Mnjama 2007).

Only one single article by Phumzile and Wamakoya (2007) touches upon the question of whether archives users find what they are looking for, but it is concerned with quantifying user satisfaction and does not ask what types of questions do not get answered by the archives. Moreover, the article focuses on academic users, neglecting the substantial use of archives for private interest, in particular genealogy, issues of citizen's rights related to documentary evidence, and local history.

\footnotetext{
3 District Six Museum www.districtsix.co.za/, Mayibuye Centre, the South African History Archive (SAHA) www.mayibuyearchives.org/, www.saha.org.za/, Nelson Mandela Foundation www. nelsonmandela.org/ (all accessed 2013-12-13).
} 
A recent issue of the International Council on Archives' journal Comma focused on recordkeeping in sub-Saharan Africa. It contains three country case studies providing a substantial historical outline of the development of archival services (in Nigeria, Tanzania, and Zimbabwe) (Abioye 2013; Magaya and Lowry 2013; Murambiwa 2013), whilst most others concentrated more on current government recordkeeping. These studies recognised the important role played by the inherited colonial records in the respective countries and mentioned post-independence efforts to supplement them by oral history, exile materials, or repatriation of displaced archives. Again, there is not even a passing hint at the role played by person-related records for non-academic users, and any efforts to deal with this issue.

The importance of person-related records is strongly referred to in awarenessraising video material of the International Records Management Trust (IRMT) (1996), using mostly African examples. These motivational videos are widely used by archivists and records managers in the quest to convince politicians and administrators of the importance of getting the very often neglected records management in government offices under control-in other words, the phases of current and semi-current records in the records life-cycle model. They do not proceed further to cover the final stages of this model, namely the appraisal and eventual destruction or permanent archiving-let alone, the actual use of the archives. This reflects the fact that the stage of archival use is present in the lifecycle model only as a distant possibility left to an undefined future client, and not as anything requiring further intervention by the archivist. This is all well for motivational public relations exercises to sell the highly important issue of proper records management to political and administrative decision-makers. It is, however, worrying that this cropped life-cycle model seems to dominate the professional archival discussion in Africa.

Whilst the academic literature on African colonial archives apparently neglects the issue of person-related records entirely, Rowell (2011) explores such problems in another settler colony, Australia, and documents a lack of archived information about approximately 500,000 Australian children removed from their families, either in a racially motivated context to enforce Western cultural values on native Australians (Aborigines) or as war-related migrants from Europe. Whilst Rowell focuses only on these specific groups of people, her article highlights the causes of neglect of their records and the subsequent psychological and practical identity problems of these individuals due to the insufficient information about their own descent. It further outlines the archival and other programmes established in Australia to address their plight. It is therefore providing valuable clues for dealing with the wider issue of the neglect of records of the colonised majority in Africa.

Similarly, the lack of person-related records (due to deliberate destruction) has also been of immediate concern in post-World War II Europe in connection with Nazi Germany's "Lebensborn" programme and the related abduction of children from a number of European countries. This problem has been tackled by intensive archival and other efforts to elucidate these children's identities and origin to assist repatriation (Valderhaug 2011; Hillel 1975). Although not strictly "colonial", these examples also arise from a context of racism, discrimination and human rights 
violation provide valuable clues about dealing with such problems in a context of colonialism and decolonisation.

\section{Conclusion}

In conclusion, the usage of colonial archives for and by non-academic users, in particular for person-related records, has so far not been systematically researched. There seems to be no single study of a previously colonial archive repository detailing which users' questions do not get answered by the archives due to gaps in its collections. Studies about the problems of archives in decolonised countries, and in particular African countries, tend to focus on problems of current records management, maintenance, training, preservation, and displaced archives. Questions about the content of colonial archives - what their collections included or excluded and how these collections support person-related inquiries by citizens-are rarely asked. Lack of research on this subject has practical implications in the delivery of archival services to citizens. If archivists are not aware of the shortcomings in the content of archival collections, they may continue relying on records management policies, collection strategies, and archival management and access facilitation practices that perpetuate the problem.

Whilst postmodern theory has contributed to a critical reading and interpretation of archival sources, it might at first appear not to be particularly helpful in targeting the apparent gaps of simple factual information which most non-academic users seek. Nevertheless, postmodernist archival thinkers may contribute more insight into recognising and possibly closing the colonial archival gaps than industrious records managers. In his thought-provoking article "Jacques Derrida meets Nelson Mandela", Harris (2011) offers no detailed analysis of the content of archives, but he does highlight the importance of working with archives. Referring to South Africa's "Truth and Reconciliation Commission" (TRC) that dealt with the legacy of the human rights abuses in apartheid South Africa, he says,

the really hard work, the work which will truly embrace damage and offer healing, remains to be done. And this challenge confronts the country in a context where the national archival and heritage systems, the 'deep memory' systems if you like, are, in truth, national systems in name only (Harris 2011, p. 117).

This observation goes right to the core of the problem. Referring to the legacy of Nelson Mandela, he then postulates: "Legacies are never received; they are only ever made and re-made:" In other words: The archives that we have inherited are not something that remains the same; it is up to each generation to earn it by working on it. This sentiment can only be underlined by any archivist who has ever organised, appraised, and described an archival fonds. It applies just as well to the legacy of colonial archives. Harris cites Derrida: "To inherit is to select, to sort, to highlight, to reactivate [...] A legacy must retain an undecidable reserve" (Harris 2011, p. 117). This is, of course, meant here in the context of interpretation of the 
inherited text. But it is just as well applicable to the discovery work required from the archivist when it comes to the seemingly missing person-related records.

Although it is not possible to recover lost records, a clear knowledge of the gaps in the collection, how they came about, and how they are related not only to written policies but also to conscious and subconscious attitudes and practices may help immensely to improve the present situation. It may bolster the argument to use surrogate records, such as (for example) church records and oral genealogies, as evidence and may lead to improved current collection strategies targeting the whole society. It may also help to develop a focused programme of discovering and indexing poorly developed resources that are present but currently undetectable.

In his keynote paper at the 6th ECARBICA Conference in Nairobi, 1980, Mazrui (1982) lamented the elite coverage, elite utilisation, and elite control of archives. He reminded archivists to cater to the "common man" (p. 8). Mazrui's contribution focused on oral tradition, but person-related records are a key issue for the "common man" and his rights, as well as a key issue for public trust in the archives. This holds especially true for the poor majority, whose living circumstances do not favour maintaining a personal collection of vital documents. From birth certificates to examination results to pension papers, people living in shacks without fire security, with leaking roofs and termites burrowing through mud-brick walls, have a constant need for lost personal documents to be replaced by the relevant national institutions. Where this cannot be done, sheer desperation opens the door for corruption and falsification.

This paper highlights the need for a detailed study of the content of national archival holdings which can guide ongoing archival strategies to target the whole society and to assist the "common man's" user enquiries with professional support. The benefits of such an approach can be demonstrated by a practical example. The accessibility of deceased estates in the NAN is currently the subject of my Ph.D. research. Worldwide, the estate records of deceased persons are a favourite source for family research. They provide authenticated information not only about the deceased, but also vital clues about family relationships which are otherwise often difficult to establish. They also remain of legal importance to settle inheritance disputes even generations later, especially in a situation of social transition and upheaval when other documents have been lost and previous traditional conflict resolution mechanisms are no longer functional.

Without pre-empting the results of my still ongoing empirical research, I can confidently state that, whilst the estates records of whites of the past 100 years have been faithfully preserved and meticulously indexed in the NAN so that they can be found with a few keystrokes, the corresponding "native" estates records present a picture of widespread neglect, non-transfer, unauthorised destruction, and lack of processing and indexing. It is quite obvious that-although official disposal instructions prescribed the preservation of "native estates" - colonial administrators and even archivists were negligent in executing their professional duties when it came to the records of the black majority.

My research is not a purely academic exercise. The realisation of this gap has led the NAN to a focused programme of indexing local magistrate transfers, which contain many person-related records including estates, although they have 
apparently only been transferred sporadically. An entire archival fonds of "Native estates" with over 7,000 records was discovered that were neither listed, nor indexed, and is now earmarked for proper processing. Preliminary research about the provenance of these fonds indicates that it had been transferred from the Chief Native Commissioner's Office at a still unknown date (NAN, NES Native Estates). The black hole of "native" records now gets increasingly filled.

Generally, the archival profession should be sensitised about the problem of gaps amongst colonial archival records and alerted to the dangers of perpetuating the status quo of the colonial legacy in current archival practices. It is hoped that such studies will raise awareness about the gaps, stir debate and lead to further research especially in other African countries regarding the contents of archival holdings and whether they are responsive to the needs of citizens. A desired outcome would be that this contributes to a major policy review of legislation, policies, guidelines, standards, principles, and procedures governing the archives and to the development of a programme of archival "affirmative action" with practical steps to rectify the wrongs of the past.

Open Access This article is distributed under the terms of the Creative Commons Attribution License which permits any use, distribution, and reproduction in any medium, provided the original author(s) and the source are credited.

\section{References}

Abioye A (2013) Milestones in archives administration in Nigeria. Comma 2012(1):15-26

Arondekar A (2005) Without a trace: sexuality and the colonial archives. J Hist Sex 14:10-27

Banton M (2012) Lost' and 'found': the concealment and release of the Foreign and Commonwealth Office 'migrated archives. Comma 2012(1):33-46

Bastian JA (2006) Reading colonial records through an archival lens. Arch Sci 6:267-284 ESARBICA Journal. (1978-) [previously ECARBICA journal] Place of publications varies

Bellamy EJ, Shetty S (2000) Postcolonialism's archive fever. Diacritics 30(1):25-48

Green R, Kiljunen K, Kiljunen M-L (1981) Namibia, the last colony. Longman, London

Hamilton C et al (eds) (2002) Refiguring the archives. David Philip, Cape Town

Harris V (2002) The archival sliver: a perspective on the construction of social memory in archives and the transition from Apartheid to democracy. In: Hamilton $\mathrm{C}$ et al (eds) Refiguring the archives. David Philip, Cape Town, pp 135-151

Harris V (2011) Jacques Derrida meets Nelson Mandela: archival ethics at the endgame. Arch Sci 11:113-124

Hillebrecht W (2013) Probleme der archivalischen Überlieferung-Lücken, Indizien und Rekonstruktionen. In: Stoecker H, Schnalke T, Winkelmann A (eds) Sammeln, Erforschen, zurückgeben? Menschliche Gebeine aus der Kolonialzeit in akademischen und musealen Sammlungen. Ch.Links Verlag, Berlin, pp 279-289

Hillel M (1975) Au nom de la race. Fayard, Paris

International Records Management Trust (1996) Protecting the people: records management and citizens' rights in Ghana. [Video; now also distributed as DVD]

Josias A (2011) Toward an understanding of archives as a feature of collective memory. Arch Sci 11:95-112

Kigongo-Bukenya IMN (1993) Education and training of archivists at the East African School of Librarianship in the 1990s and beyond. Am Arch 56:358-365

Lau B (1993) Archives services in changing societies in Southern Africa: Namibia. ESARBICA J $13: 50-60$

Lihoma P (2012) The impact of administrative change on record keeping in Malawi. University of Glasgow, PhD thesis. http://theses.gla.ac.uk/3573/. Accessed 22 Feb 2014 
Magaya CS, Lowry J (2013) The National Archives of Tanzania fifty years after Marcia Wright's Report on the government records and public archives of Tanganyika. Comma 2012(1):47-57

McEwan C (2003) Building a post-colonial archives? Gender, collective memory and citizenship. J South Afr Stud 29:739-757

Mazikana P (1997) Chapter 11. Africa. In: Large A (ed) World information report 1997/98. UNESCO, Paris, pp 144-154

Mazrui A (1982) Archives and the (un)common man: towards an indigenous theoretical framework. ECARBICA J 5:4-9

Mnjama NM (2005) Archival landscape in Eastern and Southern Africa. Lib Man 26:457-470

Mnjama NM (2007) A review of ESARBICA resolutions 1969-2005. Afr J Lib Arch Inf Sci 17:23-32

Murambiwa I (2013) Archiving to the last archivist standing: the National Archives of Zimbabwe under sanctions. Comma 2012(1):59-66

Mwiyeriwa SS (1985) The development of archives in Africa: problems and prospects. In: Wise M (ed) Aspects of African librarianship: a collection of writings. Mansell, London, pp 222-263

The National Archives [UK] (2013) Colonial administration records. The 'Migrated Archives'-record series FCO 141. http://www.nationalarchives.gov.uk/about/colonial-administration-records.htm. Accessed 13 Dec 2013

National Archives of Namibia (NAN): Private Accessions: A.0002 (Hendrik Witbooi letter-copy book); A.0003 (Maharero Papers); A.0650 (Hendrik Witbooi "Bremen" papers); AACRLS.292 (Old Location House-Owners Database). Government records: EST Estate records from the Master of the High Court; NES Native Estate records from the Chief Bantu Commissioner

Ngulube P (2005) Environmental monitoring and control at National Archives and Libraries in Eastern and Southern Africa. Libri 55:154-168

Phumzile H, Wamakoya J (2007) Utilization of archival information at Swaziland National Archives by researchers at University of Swaziland. ESARBICA J 27:85-112

Rowell H (2011) Reclaiming identity: Australia's response to children in care. Comma 1:123-134

Stoler AL (2002) Colonial archives and the arts f governance: on the content in the form. In: Hamilton C et al (eds) Refiguring the archives. David Philip, Cape Town, pp 83-100

Tough A (2009) Archives in sub-Saharan Africa half a century after independence. Arch Sci 9:187-201

UNESCO (1990) In: Adu Boahen A (ed) General history of Africa, vol. VII: Africa under colonial domination 1880-1935, Abridged edition. UNESCO, Paris

United Nations (1966) General Assembly Resolution 2145(XXI)

United Nations (1982) A crime against humanity. Questions and answers on apartheid in South Africa. United Nations Department of Public Information, New York: (DPI/705-40131)

Valderhaug G (2011) Memory, justice and the public record. Arch Sci 11:13-23

Wallace M (2011) History of Namibia until 1990. Hurst, London

Wikipedia: Vital record, http://en.wikipedia.org/wiki/Vital_record. Accessed 29 June 2014

Ellen Ndeshi Namhila Namibian born and educated in Angola, Zambia, then The Gambia and Finland. Possessed a M.D. in Library and Information Science at the University of Tampere, Finland in 1993. Currently, the University Librarian: University of Namibia and $\mathrm{PhD}$ candidate at the University of Tampere in Finland. She is the author of The Price of Freedom (1997) and winner of the 1998 Mbapira award; Kahumba Kandola Man and Myth: the Biography of a Barefoot Soldier (2005); Tears of Courage: Five Mothers Five Stories One Victory (2009); Mukwahepo: Woman Soldier, Mother (2013). Ellen wrote articles, chapters in books and delivered conference papers. Ellen worked as a Director of Namibia Library and Archives Service in the Ministry of Education (1999-2007); Deputy Director: Research, Information and Library Services at the Namibian Parliament (1995-1999); and as a researcher/librarian at the Social Sciences Division of the University of Namibia (1993-1995). Ellen served as Vice President of the UNESCO's International Advisory Committee of the Memory of the World (2007-2010); Chairperson of the National Heritage Council of Namibia (2005-2010). Ellen prepared the nomination dossier of Twyfelfontein to UNESCO's World Heritage Committee, approved in 2007 and currently accessible through UNESCO's World Heritage List; Ellen was awarded the title "Librarian of the Year 1990" in Finland. Currently, Ellen is a member of the Executive Committee of the Namibia National Commission for UNESCO and chair the Human and Social Program Committee; Chairperson of Namibia Library and Information Council (NLIC) 2011-; IFLA Governing Board member (2015-2015); IFLA Journal Editorial Committee since 2008. 